\title{
Scoring systems in the intensive care unit: A compendium
}

\author{
Amy Grace Rapsang, Devajit C. Shyam¹
}

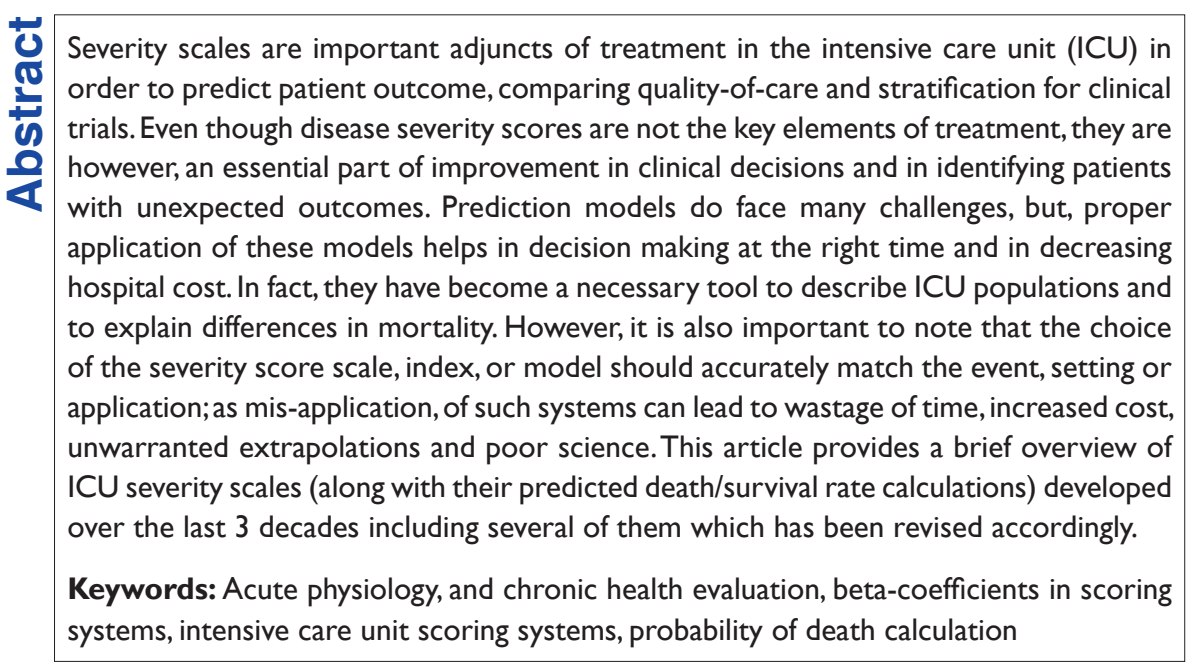

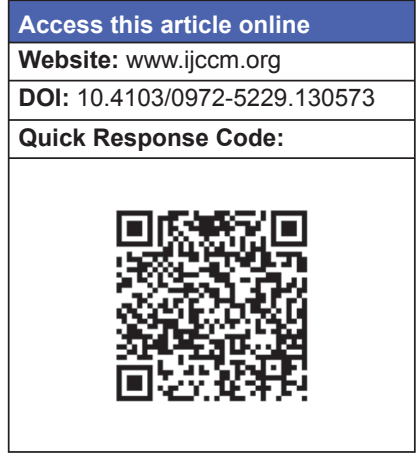

\section{Introduction}

Assessment of medical treatment outcome was started in 1863, when Florence Nightingale first addressed this issue. ${ }^{[1]}$ Initially, outcome prediction in critical illness was based on the subjective judgment of the clinicians. The rapid development of intensive care units (ICUs) created the need for quantitative and clinically relevant surrogate outcome measures in order to evaluate the effectiveness of treatment practices. Hence, scoring systems have been developed and applied for the same. The outcome of intensive care patients depends on several factors present on the $1^{\text {st }}$ day in the ICU and subsequently on the patient's course in ICU. For such populations, many scoring systems have been developed but few are used. Several of these systems are known simply by their

From:

Department of Anesthesiology and Intensive Care, Jawaharlal Institute of Post graduate Medical Education and Research, Dhanvantari Nagar, Puducherry,

${ }^{1}$ Department of General Surgery, North Eastern Indira Gandhi Regional Institute of Health and Medical Sciences, Shillong, Meghalaya, India

\section{Correspondence:}

Dr. Amy Grace Rapsang, Jawaharlal Institute of Post graduate Medical Education and Research, Dhanvantari Nagar, Puducherry, India.

E-mail: amy_rap@yahoo.com acronym. ${ }^{[2]}$ A scoring system usually comprises of two parts - a score (a number assigned to disease severity) and a probability model (equation giving the probability of hospital death of the patients). A model refines the ability of scores or scales to be used in comparing various groups of patients for the purpose of treatment, triage or comparative analysis ${ }^{[3]}$ and thus helps in decision making. They also allow an increased understanding of the effectiveness of treatment and optimizing the use of hospital resources and hence aid in the development of treatment standards. An accurate scoring model should have a high predictive power starting from day one, should not be limited to certain cut-off-points and should be calculated according to the well-known and established formula used for such a purpose with specific $\beta$-coefficients. ${ }^{[3,4]}$ The transformation of the (severity) score into a probability of death in the hospital uses a logistic regression equation. The ideal model should be well-validated, calibrated and discriminated. "Validity" is the term usually used to assess the performance of the prediction model by testing in the dataset that was used for model development. "Calibration" evaluates the accuracy of the degree of correspondence concordance 
between the estimated probabilities of mortality produced by a model and the actual mortality experienced by patients population and can be statistically evaluated using formal goodness-of-fit tests. ${ }^{[5]}$ "Discrimination" refers to the ability of the model to distinguish patients who die from patients who live, based on the estimated probabilities of mortality. Measures of discrimination are sensitivity, specificity, false positive rate, false negative rate, positive predictive power, misclassification rate, area under the receiver operating characteristic curve and concordance. ${ }^{[3]}$ This article provides the reader with an interesting compendium of ICU severity scales along with their predicted death and survival rate calculations, which can be adopted in order to improve decision making, treatment, research and in comparative analyses in quality assessment.

\section{Types of ICU Scoring Systems}

In most of the scoring systems, scores are calculated from data collected on the first ICU day - acute physiology and chronic health evaluation (APACHE), simplified acute physiology score (SAPS) and mortality prediction model (MPM). Others are repetitive and collect data every day throughout the ICU stay or for the first 3 days - organ dysfunction and infection system (ODIN), sequential organ failure assessment (SOFA), multiple organs dysfunction score (MODS), logistic organ dysfunction (LOD) model and three-day recalibrating ICU outcomes (TRIOS). Scores can be subjective or objective. ${ }^{[5]}$ Subjective scores are established by a panel of experts who choose the variables and assign a weight to each variable based on their personal opinion. E.g., APACHE II, ODIN and SOFA. Objective score variables are collected using the logistic regression modeling techniques and clinical judgment to determine ranges and to assign weights. E.g., APACHE III, SAPS II, MPM II, MODS, LOD score (LODS) and TRIOS. The commonly used ICU scoring systems (for the adult population) discussed in this article are:

- APACHE II

- SAPS II

- MODS

- SOFA

- LODS

- MPM II on admission, $24 \mathrm{~h}, 48$ h, 72 h

- ODIN

- TRIOS

- Glasgow coma score (GCS)

Many studies have shown the effectiveness of scoring systems in predicting hospital mortality and most of the available scores are comparable in terms of outcome prediction. ${ }^{[6,7]}$ Prediction models should however, periodically be updated to reflect the changes in medical practice and case-mix over time. ${ }^{[8]}$ A prospective study by Meyer $e t$ al. ${ }^{[9]}$ showed that among patients who were predicted by clinical judgment and APACHE II score to die, more than $40 \%$ of actually survived. They concluded that no method is reliable for predicting the mortality of surgical ICU patients. This raises the question of what are the desirable characteristics of risk-adjusted mortality predictors and how to avoid the confusion that exists between interpreting an estimated probability of mortality and predicting whether a given patient will live or die.

\section{APACHE //}

Developed in 1985 using a database of North American ICU patients, APACHE II [Table $1 a$ and $b]^{[1]}$ is the severity of disease classification system. It uses a point score based upon values of 12 routine physiologic measurements (taken during the first $24 \mathrm{~h}$ after admission), age and previous health status to provide a general measure of severity of disease. An integer score from 0 to 71 is then computed based on these measurements; higher scores imply a more severe disease and a higher risk of death. APACHE II scores can prognostically stratify acutely ill patients and assist investigators comparing the success of new or differing forms of therapy. If a variable has not been measured, it is assigned zero points. Hospital mortality is predicted using the APACHE II score, the principal diagnostic category with which the patient is admitted to ICU and also depending on whether or not the patient required emergency surgery. ${ }^{[1]}$ The estimated risk of hospital death is calculated using logistic regression equation, utilizing specific beta co-efficients made for its purpose [Tables $1 \mathrm{a}$ and $\mathrm{b}] .^{\left[{ }^{1]}\right.}$ In a retrospective study of 396 patients by Peter et al. ${ }^{[10]}$ the performance of the APACHE II score, the SAPS II, MPM II and the poisoning severity score (PSS) was evaluated; they found that even in the setting of poisoning, the generic scoring systems APACHE-II and SAPS-II outperform the PSS. However, the APACHE II score is neither very sensitive nor specific in terms of mortality prediction. The major limitation of this scoring system is that many patients have several co-morbid conditions and selecting only one principal diagnostic category may be very difficult. In addition, the physiological variables are all dynamic and can be influenced by multiple factors, including ongoing resuscitation and treatment, hence, time bias is present; which is an important consideration when treating patients in the ICU especially with recent increased emphasis on the importance of an early goal directed therapies. ${ }^{[11]}$ All these factors can lead to a risk of overestimation of predicted mortality. 
The APACHE III prognostic system was designed to refine APACHE II. It consists of two parts: ${ }^{[12]}$

- APACHE III score, which can provide initial risk stratification for severely ill hospitalized patients within independently defined patient groups

- APACHE III predictive equation, which uses APACHE III score and reference data on major disease categories and treatment location immediately prior to ICU admission to provide risk estimates for hospital mortality for individual ICU patients.

APACHE III largely uses the same variables as APACHE II, but a different way is used to collect the neurological data-no longer using the GCS. It adds particularly two important variables: The patient's origin and the lead-time bias. The acute diagnosis is taken into account; one diagnosis must be preferred. ${ }^{[12]}$ The APACHE III scores (evaluated as the most deranged values from the first $24 \mathrm{~h}$ in the ICU) vary between 0 and 299 points, including 252 points for the 18 physiological variables, 24 points for age and 23 points for the chronic health status; all variables are chosen to increase the explanatory power of the model. ${ }^{[13]}$

APACHE IV was gradually developed, ${ }^{[14]}$ using day 1 data for 1,16,209 ICU admissions and using the same variables as APACHE III. New variables added were: Mechanical ventilation, thrombolysis, impact of sedation on GCS, re-scaled GCS and $\mathrm{PaO}_{2} / \mathrm{FiO}_{2}$ (arterial oxygen tension and fractional concentration of inspired oxygen) ratio.

\section{SAPS I/}

First described in 1993 by Le Gall et al., ${ }^{[15]}$ SAPS II [Table 2] ${ }^{[15]}$ is used to score the ICU patients' severity. The model includes 17 variables: 12 physiologic variables, age, type of admission and three disease-related variables. As with other scoring systems, the SAPS II score registers the worst value of selected variables, within the first $24 \mathrm{~h}$ after admission. The SAPS II score can vary between 0 and 163 points (0-116 points for physiological variables, $0-17$ points for age and 0-30 points for previous diagnosis). Probability of death is then calculated using logistic regression [Table 2]. ${ }^{[15]}$ However, the discrimination and particularly the calibration of the SAPS II model

Table Ia: Acute physiologic and chronic health evaluation (APACHE II ${ }^{[1]}$

\begin{tabular}{|c|c|c|c|c|c|c|c|c|c|c|c|}
\hline \multicolumn{12}{|c|}{ A: Acute physiological score ( 12 variables) } \\
\hline \multirow{2}{*}{\multicolumn{3}{|c|}{ Physiologic variable }} & \multicolumn{4}{|c|}{ High abnormal range } & \multirow{2}{*}{$\begin{array}{c}\text { Normal range } \\
0 \\
\end{array}$} & \multicolumn{4}{|c|}{ Low abnormal range } \\
\hline & & & +4 & +3 & +2 & +1 & & +1 & +2 & +3 & +4 \\
\hline \multicolumn{3}{|c|}{ Temperature rectal $\left({ }^{\circ} \mathrm{C}\right)$} & $\geq 41$ & $39-40.9$ & - & $38.5-38.9$ & $36-38.4$ & $34-35.9$ & $32-33.9$ & $30-31.9$ & $\leq 29.0$ \\
\hline \multicolumn{3}{|c|}{ Mean arterial pressure $(\mathrm{mm} \mathrm{Hg})$} & $\geq 160$ & $130-159$ & $110-129$ & & $70-109$ & & $50-69$ & & $\leq 49$ \\
\hline \multicolumn{3}{|c|}{ Heart rate-ventricular response } & $\geq 180$ & $140-179$ & $110-139$ & & $70-109$ & & $55-69$ & $40-54$ & $\leq 39$ \\
\hline & $\geq 50$ & $35-490$ & & $25-34$ & $12-24$ & $10-11$ & $6-9$ & & $\leq 5$ \\
\hline \multicolumn{12}{|c|}{ Oxygen: $\mathrm{A}-\mathrm{a} \mathrm{DO}_{2}$ or $\mathrm{PaO}_{2}$ (Torr) } \\
\hline \multicolumn{3}{|c|}{$\begin{array}{l}\mathrm{FiO}_{2} \geq 0.5 \text { record } \mathrm{A} \text {-a } \mathrm{DO}_{2} \\
\mathrm{FiO}_{2}<0.5 \text { record only } \mathrm{PaO}_{2}\end{array}$} & $\geq 500$ & $350-499$ & $200-349$ & & $\begin{array}{c}\leq 200 \\
\mathrm{PO}_{2}>70\end{array}$ & $\mathrm{PO}_{2} 6 \mathrm{I}-70$ & & $\mathrm{PO}_{2} 55-60$ & $\mathrm{PO}_{2}<55$ \\
\hline \multicolumn{3}{|c|}{ Arterial $\mathrm{pH}$} & $\geq 7.7$ & 7.6-7.69 & & 7.5-7.59 & $7.33-7.49$ & & $7.25-7.32$ & $7.15-7.24$ & $<7.15$ \\
\hline \multicolumn{3}{|c|}{ Serum $\mathrm{HCO}_{3}(\mathrm{mmol} / \mathrm{L})$-only if no $\mathrm{ABGs}$} & $\geq 52$ & $4|-5| .9$ & & $32-40.9$ & $23-31.9$ & & $18-2 \mid .9$ & $15-17.9$ & $<15$ \\
\hline \multicolumn{3}{|c|}{ Serum sodium (mmoL/L) } & $\geq 180$ & $160-179$ & $155-159$ & $150-154$ & $130-149$ & & $120-129$ & $111-119$ & $\leq 110$ \\
\hline \multicolumn{3}{|c|}{ Serum potassium (mmoL/L) } & $\geq 7$ & $6-6.9$ & & $5.5-5.9$ & $3.5-5.4$ & $3-3.4$ & $2.5-2.9$ & & $\leq 2.5$ \\
\hline \multicolumn{3}{|c|}{ Serum creatinine $(\mu \mathrm{moL} / \mathrm{L})$} & $\geq 350$ & $200-340$ & $150-190$ & & $60-140$ & & $<60$ & & \\
\hline \multicolumn{3}{|c|}{ Hematocrit (\%) } & $\geq 60$ & & $50-50.9$ & $46-49.9$ & $30-45.9$ & & $20-29.9$ & & $\leq 20$ \\
\hline \multirow{2}{*}{\multicolumn{3}{|c|}{$\begin{array}{l}\text { White blood cell count }\left(\times 1,000 / \mathrm{mm}^{3}\right) \\
\text { Glasgow coma score }=15 \text { minus actual GCS }\end{array}$}} & $\geq 40$ & & $20-39.9$ & $15-19.9$ & $3-14.9$ & & $1-2.9$ & & $<1$ \\
\hline & & & & & & & & & & & \\
\hline \multicolumn{3}{|c|}{ B: Age points } & \multicolumn{5}{|c|}{ C: Chronic health points } & & & \multicolumn{2}{|c|}{ Apache II score } \\
\hline Age (years) & Points & History & & & & \multicolumn{2}{|c|}{$\begin{array}{l}\text { Points for } \\
\text { elective surgery }\end{array}$} & \multicolumn{2}{|c|}{$\begin{array}{l}\text { Points for } \\
\text { emergency surgery }\end{array}$} & \multicolumn{2}{|c|}{$\begin{array}{l}\text { Sum of } \\
A+B+C\end{array}$} \\
\hline$\leq 44$ & 0 & \multicolumn{4}{|c|}{$\begin{array}{l}\text { Liver: Biopsy-proven cirrhosis and documented portal } \\
\text { hypertension or prior episodes of hepatic failure }\end{array}$} & \multicolumn{2}{|r|}{2} & \multicolumn{2}{|l|}{5} & \multicolumn{2}{|l|}{ A: APS } \\
\hline $45-54$ & 2 & \multicolumn{4}{|c|}{ Cardiovascular: NYHA Class IV } & & 2 & 5 & & B: Age $p$ & oints \\
\hline $55-64$ & 3 & $\begin{array}{l}\text { Respiratory: e.g., severe } \mathrm{CC} \\
\mathrm{O}_{2} \text {, pulmonary hypertensio }\end{array}$ & DPD, hy & ypercapnia & a, home & & 2 & 5 & & score & \\
\hline $65-74$ & 5 & Immunocompromised & & & & & 2 & 5 & & C: Chro & nic health \\
\hline$\geq 75$ & 6 & Renal: Chronic dialysis & & & & & 2 & 5 & & point sc & ore \\
\hline
\end{tabular}

Total score

APACHE: Acute physiology and chronic health evaluation; A-a $\mathrm{DO}_{2}$ : Alveolar-arterial oxygen tension difference; $\mathrm{PaO}_{2}$ (Torr) arterial oxygen tension; FiO ${ }_{2}(\%)$ : Fractional concentration of inspired oxygen; $\mathrm{HCO}_{3}$ : Bicarbonate; ABG: Arterial blood gas; NYHA: New York heart association; COPD: Chronic obstructive pulmonary disease. To compute predicted death rates for groups of acutely ill patients, the individual risk of hospital death is calculated with the following equation; the individual risks are then summed up and the value is divided by the total number of patients. $R / I-R=-3.5 I 7+($ APACHE II score $\times 0.146)+(0.603$, only if post-emergency surgery $)+($ diagnostic category weight as shown below), where $R$ is the estimated risk of hospital death 
do not fit when applied to a new population. Therefore, to calculate the standardized mortality ratio or the ICU performance measure, a proposal was recently made by Le Gall et al., ${ }^{[16]}$ where six admission variables were added to SAPS II: Age, sex, length of the ICU hospital stay, patient location before ICU, clinical category and whether drug overdose was present or not. Probability of death $(P)$ for this expanded model is again calculated using logistic regression, where:

A world-wide database of 19,577 patients was then used to develop SAPS III in $2005,{ }^{[17,18]}$ comprising of three parts: chronic variables, acute variables including the sepsis and its characteristics and physiology. Data are acquired within $1^{\text {st }} \mathrm{h}$ of admission. The calculated probability of ICU and hospital death emerges by adding diagnoses to the model. Recently, Liu et al., developed an electronic SAPS 3, which was tested among 67,889 first-time ICU admissions at 21 hospitals between 2007 and 2011 to predict hospital mortality. This customized eSAPS 3 version was also developed in a $40 \%$ derivation cohort and tested in a $60 \%$ validation cohort; they concluded that this eSAPS 3 shows good potential for providing automated risk adjustment in the ICU. ${ }^{[19]}$

\section{MODS}

In an article in 1995 Marshall et al. ${ }^{[20]}$ proposed an objective scale to measure the severity of multiple organ dysfunction as an outcome in critical illness and tested these criteria in a population of 692 patients. They developed the MODS [Table 3], ${ }^{[20]}$ which comprises a score based on six organ failures. Scores were given from 0 to 4 (maximum of 24). Hospital mortality is then estimated after adding the total scores [Table 3]. ${ }^{[20]}$ This score correlated in a graded fashion with the ICU mortality rate, both when applied on the first day of ICU admission as a prognostic indicator and when calculated over the ICU stay as an outcome measure. The score showed excellent discrimination and that mortality depends not only on the admission score but also on the course of ICU stay and therefore, may prove useful

\begin{tabular}{|c|c|c|c|}
\hline Non-operative & $\mathbf{Y}$ & Post-operative patients & $\mathbf{Y}$ \\
\hline Respiratory failure or insufficiency from & & Multiple trauma & -1.684 \\
\hline Asthma/allergy & -2.108 & Admission due to chronic cardiovascular disease & -1.376 \\
\hline COPD & -0.367 & Peripheral vascular surgery & -1.315 \\
\hline Pulmonary edema (non-cardiogenic) & -0.251 & Heart valve surgery & $-1.26 \mid$ \\
\hline Post-respiratory arrest & -0.168 & Craniotomy for neoplasm & -1.245 \\
\hline Aspiration/poisoning/toxic & -0.142 & Renal surgery for neoplasm & -1.204 \\
\hline Pulmonary embolus & -0.128 & Renal transplant & -1.042 \\
\hline Infection & 0 & Head trauma & -0.955 \\
\hline Neoplasm & 0.891 & Thoracic surgery for neoplasm & -0.802 \\
\hline Cardiovascular failure or insufficiency from & & Craniotomy for ICH/SDH/SAH & -0.788 \\
\hline Hypertension & -1.798 & Laminectomy and other spinal cord surgery & -0.699 \\
\hline Rythm disturbance & -1.368 & Hemorrhagic shock & -0.682 \\
\hline Congestive heart failure & -0.424 & Gl bleeding & -0.617 \\
\hline Hemorrhagic shock/hypovolemia & 0.493 & Gl surgery for neoplasm & -0.248 \\
\hline Coronary artery disease & -0.191 & Respiratory insufficiency & -0.140 \\
\hline Sepsis & 0.113 & Gl perforation/obstruction & 0.060 \\
\hline Post cardiac arrest & 0.393 & $\begin{array}{l}\text { If not in one of the above, which major vital } \\
\text { organ system led to ICU admission post-surgery }\end{array}$ & \\
\hline Cardiogenic shock & -0.259 & Neurologic & -1.150 \\
\hline Dissecting thoracic/abdomina aneurysm & 0.731 & Cardiovascular & -0.797 \\
\hline Trauma & & Respiratory & -0.610 \\
\hline Multiple trauma & -1.228 & Gastro-intestinal & -0.613 \\
\hline Head injury & -0.517 & Metabolic/renal & -0.19 \\
\hline \multicolumn{4}{|l|}{ Neurologic } \\
\hline Seizure disorder & -0.584 & & \\
\hline $\mathrm{ICH} / \mathrm{SDH} / \mathrm{SAH}$ & 0.723 & & \\
\hline \multicolumn{4}{|l|}{ Other } \\
\hline Drug overdose & -3.353 & & \\
\hline Diabetic ketoacidosis & -1.507 & & \\
\hline Gastro intestinal bleeding & 0.334 & & \\
\hline \multicolumn{4}{|c|}{$\begin{array}{l}\text { If not in one of the groups above, which major } \\
\text { organ system was the principal reason for admission }\end{array}$} \\
\hline Metabolic/renal & -0.885 & & \\
\hline Respiratory & -0.890 & & \\
\hline Neurologic & -0.759 & & \\
\hline Cardiovascular & 0.470 & & \\
\hline Gl & 0.501 & & \\
\hline
\end{tabular}




\begin{tabular}{|c|c|c|c|c|c|c|c|c|c|c|c|c|c|c|c|c|c|c|c|c|}
\hline \multirow[t]{2}{*}{ Variables } & \multicolumn{20}{|c|}{ Score } \\
\hline & 26 & 13 & 12 & II & 9 & 7 & 6 & 5 & 4 & 3 & 2 & 0 & I & 2 & 3 & 4 & 6 & 7 & 9 & 10 \\
\hline HR (beats/min) & & & & $<40$ & & & & & & & $40-69$ & $70-119$ & & & & $120-159$ & & $\geq 160$ & & \\
\hline $\mathrm{SBP}(\mathrm{mmHg})$ & & $<70$ & & & & & & $70-99$ & & & & $100-199$ & & $\geq 200$ & & & & & & \\
\hline Temperature $\left({ }^{\circ} \mathrm{C}\right)$ & & & & & & & & & & & & $<39$ & & & $\geq 39$ & & & & & \\
\hline $\begin{array}{l}\mathrm{PaO}_{2} / \mathrm{FiO}_{2} \text { only if } \\
\text { VENT or CPAP }\end{array}$ & & & & $<100$ & $00-199$ & $\geq 200$ & & & & & & & & & & & & & & \\
\hline Urine output (L/day) & & & & $<0.5$ & & & & & $0.5-0.999$ & & & $\geq 1$ & & & & & & & & \\
\hline Urea $(g / L)$ & & & & & & & & & & & & $<0.6$ & & & & & $0.6-1.7$ & & & $>1.8$ \\
\hline TLC & & & $<1$ & & & & & & & & & $1-19.9$ & & $\geq 20$ & & & & & & \\
\hline Potassium & & & & & & & & & & $<3$ & & $3-4.9$ & & $\geq 5$ & & & & & & \\
\hline Sodium & & & & & & & & $<125$ & & & & I25-144 & $\geq 145$ & & & & & & & \\
\hline Bicarbonate & & & & & & & $<15$ & & & $15-19$ & & $>20$ & & & & & & & & \\
\hline Bilirubin (mg/dl) & & & & & & & & & & & & $<40$ & & & & $40-59.9$ & & & $\geq 60$ & \\
\hline GCS & $<6$ & $6-8$ & & & & $9-10$ & & $11-13$ & & & & $14-15$ & & & & & & & & \\
\hline Age & & & & ore & & & Chron & nic dise & ase & & Score & & & ype of & admis & ssion & & Scor & & \\
\hline$<40$ & & & c & 0 & & & Metast & tatic can & cer & & 9 & & & Schedule & ed surg & gical & & 0 & & \\
\hline $40-59$ & & & 7 & 7 & & Hem & hatolog & gical ma & lignancy & & 10 & & & & edical & & & 6 & & \\
\hline $60-69$ & & & I & 2 & & & & AIDS & & & 17 & & & mergen & hcy sur & cgical & & 8 & & \\
\hline $70-74$ & & & I & 5 & & & & & & & & & & & & & & & & \\
\hline $75-79$ & & & I & 6 & & & & & & & & & & & & & & & & \\
\hline$>80$ & & & I & 8 & & & & & & & & & & & & & & & & \\
\hline SAPS II score & & & 2 & 29 & & & & 40 & & & 52 & & & & 64 & & & 77 & & \\
\hline Mortality risk \% & & & & 0 & & & & 25 & & & 50 & & & & 75 & & & 90 & & \\
\hline
\end{tabular}

GCS: Glasgow coma score; HR: Heart rate; SBP: Systolic blood pressure; $\mathrm{PaO}_{2}(\mathrm{~mm} \mathrm{Hg})$ arterial oxygen tension; FiO ${ }_{2}$ Fractional concentration of inspired oxygen; VENT: Ventilator; CPAP: Continuous positive airway pressure; TLC: Total leukocyte count; AIDS: Acquired immunodeficiency syndrome. Probability of death, $P$ may be calculated using the following equation: $P=\left(\mathrm{e}^{\text {Logit }}\right) /\left(I+\mathrm{e}^{\text {Logit }}\right)$; Logit $=-7.763 I+0.0737($ score $)+0.997 I(\log [$ score $+I])$

as an alternative end point for clinical trials involving critically ill patients.

\section{SOFA}

The SOFA system [Table 4] was created in a consensus meeting of the European Society of Intensive Care Medicine in 1994 and further revised in 1996. ${ }^{[21]}$ In 1998, Vincent et al. ${ }^{[22]}$ evaluated the SOFA subjective score on 1449 patients. This score was developed to quantify the severity of patients illness, based on the degree of organ dysfunction data on six organ failures and are scored on a scale of $0-4$. One failure plus a respiratory failure indicate the lowest mortality; all the other combinations yield mortality between $65 \%$ and $74 \%$. Subsequent analyses have considered the maximal score plus the maximal change and have shown that the latter has a lower prognostic value than the former; the time course of the patient's condition during the entire ICU stay is also taken into account. ${ }^{[23]}$ Although there is no direct conversion of SOFA score to mortality, a rough estimate of mortality risk may be made based on two prospective papers that have been published [Table 4]. ${ }^{[21,22,24]}$

Sequential assessment of organ dysfunction during the first few days of ICU admission is a good indicator of prognosis. A prospective study by Bale et al. showed that both the mean and highest SOFA scores are particularly useful predictors of outcome, independent of the initial score and a high SOFA score at $48 \mathrm{~h}$ of presentation
Table 3: Multiple organ dysfunction score ${ }^{[20]}$

\begin{tabular}{|c|c|c|c|c|c|}
\hline \multicolumn{6}{|c|}{ Multiple organ dysfunction score } \\
\hline \multirow{2}{*}{$\begin{array}{l}\text { Organ system and their } \\
\text { variables }\end{array}$} & \multicolumn{5}{|c|}{ Score } \\
\hline & 0 & I & 2 & 3 & 4 \\
\hline $\begin{array}{l}\text { Hematologic: Platelet } \\
\text { count }\left(\times 10^{3} / \mathrm{mm}^{3} \text { or } 10^{9} / \mathrm{L}\right)\end{array}$ & $>120$ & $81-120$ & $5 I-80$ & $21-50$ & $\leq 20$ \\
\hline $\begin{array}{l}\text { Hepatic: Serum } \\
\text { bilirubin }(\mu \mathrm{mol} / \mathrm{L})\end{array}$ & $\leq 20$ & $21-60$ & $61-120$ & $|2|-240$ & $>240$ \\
\hline $\begin{array}{l}\text { Renal: Serum } \\
\text { creatinine }(\mu \mathrm{mol} / \mathrm{L})\end{array}$ & $\leq 100$ & $10 \mid-200$ & $20 I-350$ & $35 I-500$ & $>500$ \\
\hline Cardiovascular: PAR* & $\leq 10$ & $10.1-15$ & I5. I-20 & $21-30$ & $>30$ \\
\hline Glasgow coma score & 15 & $13-14$ & $10-12$ & $7-9$ & $\leq 6$ \\
\hline Respiratory: $\mathrm{PO}_{2} / \mathrm{FiO}_{2}$ & $>300$ & $226-300$ & $15 \mid-225$ & $76-150$ & $\leq 75$ \\
\hline Score & 0 & $\mathrm{I}-4$ & $5-8 \quad 9-12$ & $13-16 \quad 17-20$ & $21-24$ \\
\hline ICU mortality \% & 0 & $\mathrm{I}-2$ & $3-5 \quad 25$ & 50 & 100 \\
\hline
\end{tabular}

ICU: Intensive care unit; CVP: Central venous pressure ( $\mathrm{mmHg})$; GCS: Glasgow coma score; HR: Heart rate (beats/min); MAP: Mean arterial pressure $(\mathrm{mmHg})$; PAR: Pressure adjusted heat rate (which is calculated as the product of the HR and the ratio of CVP to MAP); $\mathrm{PaO}_{2}$ (Torr) arterial oxygen tension; $\mathrm{FiO}_{2}$ : Fractional concentration of inspired oxygen. If the result for a specific test is not available, then a score of 0 is used for that test. The serum creatinine concentration is measured without the use of dialysis and the $\mathrm{PO}_{2} / \mathrm{FiO}_{2}$ ratio $\left(\mathrm{PO}_{2}\right.$ in $\mathrm{mmHg}$ and $\mathrm{FiO}_{2}$ in \%) is calculated without the use of mechanical ventilation or positive end-expiratory pressure

predicts an increased mortality rate. ${ }^{[25]}$ In their study, Ferreira et al..$^{[24]}$ determined that, regardless of the initial score, an increase in SOFA score during the first 48 $\mathrm{h}$ in the ICU predicts a mortality rate of at least $50 \%$. Vosylius et al..$^{[26]}$ showed that cumulative SOFA scores were better in discriminating outcome compared to a single organ dysfunction scores. A study published in 2007, Grissom et al. ${ }^{[27]}$ proposed and published a simplified version of the SOFA score known as the 
Modified SOFA (MSOFA) score. The MSOFA score eliminates the necessity of laboratory examinations such as the platelet count and substitute measurements of $\mathrm{PaO}_{2} / \mathrm{FiO}_{2}$ and serum bilirubin level with the $\mathrm{SPO}_{2} / \mathrm{FiO}_{2}$ ratio (obtained by dividing pulse oxymeter saturation with a fraction of inspired oxygen) and clinical examination for jaundice. Although simpler, this score has to have more validation.

\section{LODS}

Le Gall et al. ${ }^{[28]}$ initially proposed the LODS [Table 5] ${ }^{[7,28,29]}$ in 1996, where 12 variables were tested and six organ failures defined. The model has been tested over time. The difference between the LODS on day 3 and day 1 is highly predictive of the hospital outcome. The LODS was designed to combine measurement of the severity of multiple organ dysfunctions into a single score. The probability of death is then calculated using an equation designed for its purpose [Table 5]. ${ }^{[7,28,29]}$
In a prospective multicenter study on 1685 ICU patients, Timsit et al. ${ }^{[29]}$ concluded that daily LOD and SOFA scores showed good accuracy and internal consistency and they could be used to adjust the severity for events occurring in the ICU. Another prospective study by Kim and Yoon in 521 consecutive patients admitted to the neurological ICU, showed that both the LODS and the APACHE II score had excellent discrimination but LODS had superior calibration; they therefore, concluded that the LODS was more stable than the APACHE II scoring system in the neurological ICU setting. ${ }^{[30]}$ However, Maccariello et al. ${ }^{[7]}$ evaluated the performance of LODS in patients receiving renal replacement therapy and found poor correlation between LODS score and predicted mortality rate. They attributed this poor correlation to the fact that it was studied in an older and rather severely ill population due to high frequencies of comorbidity, sepsis, functional capacity impairment and need for mechanical ventilation and vasoactive amines.

\begin{tabular}{|c|c|c|c|c|c|c|}
\hline \multirow{2}{*}{$\begin{array}{l}\text { Organ } \\
\text { system }\end{array}$} & \multicolumn{6}{|c|}{ Score } \\
\hline & Variable & 0 & I & 2 & 3 & 4 \\
\hline Pulmonary & Lowest $\mathrm{PaO}_{2}($ Torr $) / \mathrm{FiO}_{2}(\%)$ & $>400$ & $\leq 400$ & $\leq 300$ & $\begin{array}{c}\leq 200+\text { respiratory } \\
\text { support }\end{array}$ & $\begin{array}{c}\leq 100+\text { respiratory } \\
\text { support }\end{array}$ \\
\hline Coagulation & Lowest platelet $\left(10^{3} / \mathrm{mm}^{3}\right)$ & $>150$ & $\leq 150$ & $\leq 100$ & $\leq 50$ & $\leq 20$ \\
\hline Hepatic & Highest bilirubin $(\mu \mathrm{mol} / \mathrm{L})$ & $<20$ & $20-32$ & $33-101$ & $102-204$ & $>204$ \\
\hline Circulatory & Blood pressure status & $\begin{array}{c}\text { Mean arterial } \\
\text { pressure } \\
(\mathrm{mmHg})>70\end{array}$ & $\begin{array}{c}\text { Mean arterial } \\
\text { pressure } \\
(\mathrm{mmHg})<70\end{array}$ & $\begin{array}{c}\text { Dopamine* dose } \leq 5 \\
\text { or dobutamine any } \\
\text { dose }\end{array}$ & $\begin{array}{c}\text { Dopamine dose }>5 \text { or } \\
\text { epinephrine } \leq 0.1 \text { or } \\
\text { norepinephrine } \leq 0.1\end{array}$ & $\begin{array}{c}\text { Dopamine dose }>15 \\
\text { or epinephrine }>0.1 \text { or } \\
\text { norepinephrine }>0.1\end{array}$ \\
\hline Neurologic & GCS & 15 & $13-14$ & $10-12$ & $6-9$ & $<6$ \\
\hline \multirow[t]{2}{*}{ Renal } & Highest creatinine level $(\mu \mathrm{mol} / \mathrm{L})$ & $<110$ & $110-170$ & $171-299$ & $300-440$ & $>440$ \\
\hline & Total urine output $(\mathrm{mL} / 24 \mathrm{~h})$ & & & & $<500$ & $<200$ \\
\hline Score & $0-6$ & $7-9$ & $10-12$ & $13-14$ & 15 & $15-24$ \\
\hline Score \% & $<10$ & $15-20$ & $15-20$ & $50-60$ & $>80$ & $>90$ \\
\hline
\end{tabular}

$\mathrm{PaO}_{2}$ : (Torr) arterial oxygen tension; $\mathrm{FiO}_{2}$ : Fractional concentration of inspired oxygen; GCS: Glasgow coma score

\begin{tabular}{|c|c|c|c|c|c|c|c|}
\hline Measurements of organic systems & 5 & 3 & I & $\mathbf{0}$ & I & 3 & 5 \\
\hline Neurological (GCS) & $3-5$ & $6-8$ & $9-13$ & $14-15$ & & & \\
\hline \multicolumn{8}{|l|}{ Cardiovascular } \\
\hline HR (beats/min) & $<30$ & $40-69$ & $70-89$ & $30-139$ & $\geq 140$ & & \\
\hline $\mathrm{SBP}(\mathrm{mmHg})$ & $<40$ & & & $0-239$ & $240-269$ & $\geq 270$ & \\
\hline \multicolumn{8}{|l|}{ Renal } \\
\hline Ureic nitrogen (mmol/L) & - & - & - & $<6$ & $6-9.98$ & $9.99-19.98$ & $\geq 19.99$ \\
\hline Serum creatinine $(\mu \mathrm{mol} / \mathrm{L})$ & - & - & - & $<106.08$ & $106.08-140.55$ & $\geq 141.44$ & - \\
\hline Urine output (L/24 h) & $<0.5$ & $0.5-0.74$ & - & $0.75-0.99$ & - & $\geq 10$ & - \\
\hline \multicolumn{8}{|l|}{ Respiratory } \\
\hline $\mathrm{PaO}_{2}($ Torr $) / \mathrm{FiO}_{2}(\%)$ in $\mathrm{MV}$ or CPAP & - & $<150$ & $\geq 150$ & With no ventilation, CPAP or IPAP & - & - & - \\
\hline \multicolumn{8}{|l|}{ Hematologic } \\
\hline $\operatorname{TLC}\left(\mathrm{mm}^{3}\right) \times 10^{3}$ & - & $<1.0$ & I.0-2.4 & $2.5-49.9$ & $\geq 50$ & - & - \\
\hline Platelets $\left(\mathrm{mm}^{3}\right) \times 10^{3}$ & - & - & $<50$ & $\geq 50$ & - & - & - \\
\hline \multicolumn{8}{|l|}{ Hepatic } \\
\hline Serum bilirubin $(\mu \mathrm{mol} / \mathrm{L})$ & & & & $<34.2$ & $\geq 34.2$ & & \\
\hline PT (seconds and \%) & & & $<25$ & $<3 \mathrm{~s},>25$ & $\geq 3 \mathrm{~s}$ & & \\
\hline
\end{tabular}

LOD: Logistic organ dysfunction; GCS: Glasgow coma score; HR: Heart rate; SBP: Systolic blood pressure; PaO ${ }_{2}$ ( Torr) arterial oxygen tension; FiO $:$ Fractional concentration of inspired oxygen; MV: Mechanical ventilation, CPAP: Continued positive airways pressure; IPAP: Intermittent positive airways pressure; TLC: Total leucocyte count; PT: Prothrombin time. The probability of death is then calculated using the formula: Probability of death $=\mathrm{e}^{\text {logit }} /\left(\mathrm{I}+\mathrm{e}^{\operatorname{logit}}\right)$. Logit $=-3.4043+0.4 \mathrm{I} 73$ (LOD score) 


\section{MPM II}

First described by Lemeshow et al. ${ }^{[31]}$ MPM II [Table 6] is a model giving the probability of hospital death directly. Four models have been proposed: MPM II at admission and at 24, 48 and $72 \mathrm{~h}$. The initial version of this model was designed to predict mortality at hospital discharge based on data from admission and after the first $24 \mathrm{~h}$ in the ICU. ${ }^{[32]}$ Additional models were later developed and included data from 48 to $72 \mathrm{~h}$ after admission to the ICU. This model uses chronic health status, acute diagnosis, a few physiological variables and some other variables including mechanical ventilation. The MPM II at 48 and $72 \mathrm{~h}$ use the same variables as MPM II at $24 \mathrm{~h}$ and are based on the most deranged values of the preceding 24

\begin{tabular}{|c|c|c|}
\hline Variables & $\begin{array}{c}\text { Values ( } I \text { if yes, } \\
0 \text { otherwise) } \\
\text { except for age }\end{array}$ & $\begin{array}{c}\text { Beta } \\
\text { coefficients }\end{array}$ \\
\hline \multicolumn{3}{|l|}{ MPM II-admission } \\
\hline $\begin{array}{l}\text { Medical or unscheduled surgery } \\
\text { admission }\end{array}$ & $\mathrm{I} / 0$ & I.19098 \\
\hline Metastatic neoplasm & $\mathrm{I} / 0$ & I.19979 \\
\hline Cirrhosis & $\mathrm{I} / 0$ & I. $1368 \mid$ \\
\hline Chronic renal insufficiency & $\mathrm{I} / 0$ & 0.91906 \\
\hline CPR prior to admission & $\mathrm{I} / 0$ & 0.56995 \\
\hline Coma (GCS 3-5) & $\mathrm{I} / 0$ & 1.48592 \\
\hline Heart rate $\geq 150$ & $\mathrm{I} / 0$ & 0.45603 \\
\hline $\mathrm{SBP} \leq 90 \mathrm{mmHg}$ & $\mathrm{I} / 0$ & 1.06127 \\
\hline Acute renal insufficiency & $1 / 0$ & 1.48210 \\
\hline Cardiac dysrhythmia & $1 / 0$ & 0.28095 \\
\hline Cerebrovascular incident & $1 / 0$ & 0.21338 \\
\hline GI bleeding & $1 / 0$ & 0.39653 \\
\hline Intracranial mass effect & $1 / 0$ & 0.86533 \\
\hline Mechanical ventilation & $1 / 0$ & 0.79105 \\
\hline \multicolumn{3}{|l|}{ Age } \\
\hline \multicolumn{3}{|l|}{ MPM II-24, 48, $72 \mathrm{~h}$} \\
\hline $\begin{array}{l}\text { Medical or unscheduled surgery } \\
\text { admission }\end{array}$ & $\mathrm{I} / 0$ & 0.83404 \\
\hline Metastatic neoplasm & $\mathrm{I} / 0$ & 1.16109 \\
\hline Cirrhosis & $\mathrm{I} / 0$ & $\mathrm{I} .08745$ \\
\hline Creatinine $>$ I $77 \mu \mathrm{mol} / \mathrm{L}$ & $\mathrm{I} / 0$ & 0.72283 \\
\hline Urine output $<50 \mathrm{~mL} / 8 \mathrm{~h}$ & $\mathrm{I} / 0$ & 0.82286 \\
\hline Coma (GCS 3-5) & $1 / 0$ & 1.68790 \\
\hline Confirmed infection & $1 / 0$ & 0.49742 \\
\hline Intracranial mass effect & $1 / 0$ & 0.91314 \\
\hline Mechanical ventilation & $1 / 0$ & 0.80845 \\
\hline Vasoactive drugs $\geq \mathrm{I} h$ & $\mathrm{I} / 0$ & 0.71628 \\
\hline $\mathrm{PaO}_{2}<60$ Torr $(<7.98 \mathrm{kPa})$ & $\mathrm{I} / 0$ & 0.46677 \\
\hline Prothrombin time $>$ standard $+3 \mathrm{~s}$ & $1 / 0$ & 0.55352 \\
\hline \multicolumn{3}{|l|}{ Age } \\
\hline \multicolumn{3}{|c|}{ 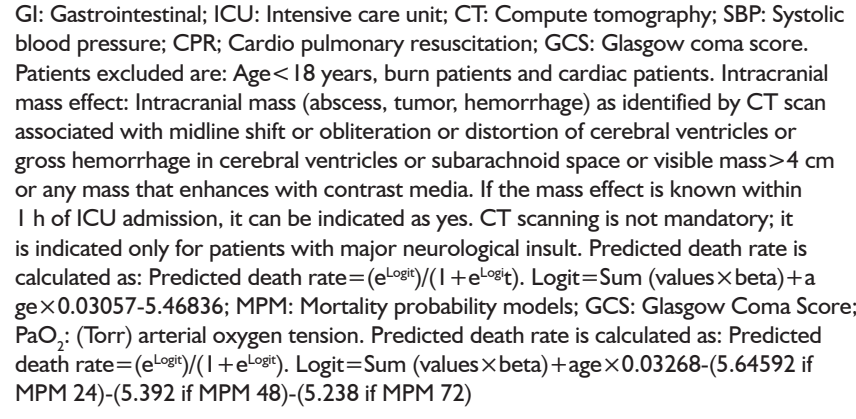 } \\
\hline
\end{tabular}

$\mathrm{h}$ with different weights to compute the probabilities of death using logistic regression [Table 6]. ${ }^{[3,34]}$

\section{ODIN System}

Fagon et al. ${ }^{[35]}$ proposed the ODIN system [Table 7 $]^{[7,35]}$ in 1993. This includes data recorded within the first $24 \mathrm{~h}$ of ICU admission if there is any presence or absence of dysfunction in six organs plus one infection and it differentiates the prognosis according to the type of failures; the highest mortality rates was found to be associated with hepatic followed by hematologic and renal dysfunctions and the lowest with respiratory dysfunction and infection. Taking into account both the number and the type of organ dysfunction, a logistic regression model was then used to calculate individual probabilities of death that depended upon the statistical weight assigned to each ODIN (in the following order of descending severity: Cardiovascular, renal, respiratory, neurologic, hematologic, hepatic dysfunctions and infection).

\section{TRIOS}

In 2001, Timsit et al. ${ }^{[36]}$ proposed a composite score, the TRIOS [Table 8], ${ }^{[36]}$ using daily SAPS II and LODS for predicting hospital hospitality in ICU patients hospitalized for more $72 \mathrm{~h}$. Using logistic regression, the probability of hospital mortality can be computed [Table 8] ${ }^{[36]}$ This TRIOS composite score has excellent statistical qualities and may be used for research purposes..$^{[5]}$

\begin{tabular}{|c|c|c|}
\hline $\begin{array}{l}\text { Organ system } \\
\text { dysfunction }\end{array}$ & Variables & $\begin{array}{l}\text { Values ( } \mathrm{I} \text { if yes, } \\
0 \text { otherwise) }\end{array}$ \\
\hline Respiratory & $\begin{array}{l}\mathrm{PaO}_{2}<60 \text { Torr }\left(\mathrm{FiO}_{2}=0.2 \mathrm{I}\right) \text { or need for } \\
\text { ventilatory support }\end{array}$ & \\
\hline Cardiovascular & $\begin{array}{l}\mathrm{SBP}<90 \mathrm{mmHg} \text { with signs of } \\
\text { peripheral hypoperfusion or continuous } \\
\text { infusion of vasopressor or inotropic } \\
\text { agent to maintain } \mathrm{SBP}>90 \mathrm{mmHg}\end{array}$ & \\
\hline Renal & $\begin{array}{l}\text { Serum creatinine }>300 \mu \mathrm{mol} / \mathrm{L} \text { or urine } \\
\text { output }<500 \mathrm{~mL} / 24 \mathrm{~h} \text { or }<180 \mathrm{~mL} / 8 \mathrm{~h} \\
\text { or need for hemodialysis or peritoneal } \\
\text { dialysis }\end{array}$ & \\
\hline Neurologic & $\begin{array}{l}\text { GCS }<6 \text { (in absence of sedation at any } \\
\text { time in the day) or sudden onset of } \\
\text { confusion or psychosis }\end{array}$ & \\
\hline Hepatic & $\begin{array}{l}\text { Serum bilirubin }>100 \mu \mathrm{mol} / \mathrm{L} \text { or alkaline } \\
\text { phosphatase }>3 \text { times normal value }\end{array}$ & \\
\hline Hematologic & $\begin{array}{l}\text { Hematocrit } \leq 20 \% \text { or TLC }<2000 / \mathrm{mm}^{3} \\
\text { or platelet count }<40000 / \mathrm{mm}^{3}\end{array}$ & \\
\hline $\begin{array}{l}\text { Infection (with } \\
\text { clinical } \\
\text { evidence) }\end{array}$ & $\begin{array}{l}2 \text { positive blood cultures or presence } \\
\text { of gross pus in a closed space or source } \\
\text { of the infection determined during } \\
\text { hospitalization or at autopsy in case of } \\
\text { death within the } 24 \mathrm{~h}\end{array}$ & \\
\hline $\begin{array}{l}\mathrm{PaO}_{2}:(\text { Torr }) \text { arteria } \\
\text { oxygen; } \mathrm{SBP}: \text { Systo } \\
\text { leucocyte count. } \mathrm{Pr} \\
\text { death }=\mathrm{e}^{\text {logit }} /\left(\mathrm{I}+\mathrm{e}^{\mathrm{log}}\right. \\
8 \times \text { renal })+(0.86 \times \mathrm{l}\end{array}$ & $\begin{array}{l}\text { al oxygen tension; } \mathrm{FiO}_{2} \text { : Fractional concentration } \\
\text { lic Blood Pressure; } \mathrm{GCS} \text { : Glasgow coma score; } \\
\text { robability of death is calculated using the formul } \\
\text { git }) \text {. Logit }=-3.59+(\mathrm{I} .09 \times \text { respiratory })+(1.19 \times 0 \\
\text { hematologic }+(0.57 \times \text { liver })+(0.99 \times \text { neurologic })\end{array}$ & $\begin{array}{l}n \text { of inspired } \\
\text { TLC: Total } \\
\text { la: Probability of } \\
\text { cardiovascular })+(1.1 \\
+(0.53 \times \text { infection })\end{array}$ \\
\hline
\end{tabular}




\section{GCS}

The GCS [Table 9] is a universal tool for the rapid assessment of an injured ${ }^{[37]}$ patient's consciousness level and as a guide to the severity of brain injury. ${ }^{[38]}$ Several studies have shown that there is a good correlation between GCS and neurological outcome. ${ }^{[39,40]}$ A modified verbal and motor version has been developed to aid in the evaluation of the consciousness level of infants and children. ${ }^{[41,42]}$ [Table 9].

\begin{tabular}{lr}
\hline Table 8: TRIOS (3 days recalibrated ICU outcome score) & \\
\hline Variables & Value: I if yes, 0 otherwise \\
(except for LODS and \\
SAPS II admission)
\end{tabular}

Transfer from ward

Chronic illness

SAPS II day 2-SAPS II day 3 alteration

LODS day 2-LODS day 3 alteration

LODS on admission

SAPS II on admission

TRIOS: Three-day recalibrating ICU outcomes; ICU: Intensive care unit; LODS: Logistic organ dysfunction score; SAPS: Simplified acute physiology score.

To compute the probability of hospital mortality, $P: P\left(\mathrm{e}^{\mathrm{Logit}}\right) /\left(1+\mathrm{e}^{\mathrm{Logit}}\right)$ where $\mathrm{e}=2.7182818$ (the base of the natural logarithm). Logit $=(-4.44)+0.5543$ (transfer from ward) +0.1536 (LOD on admission) +0.0388 (SAPS II on admission) +0.8507 (chronic illness)+0.416I (SAPS2-SAPS3 alteration) +0.6940 (LOD2-LOD3 alteration)

\begin{tabular}{|c|c|c|c|c|}
\hline \multicolumn{5}{|c|}{ Table 9: Glasgow coma score ${ }^{[37]}$} \\
\hline \multicolumn{3}{|l|}{ Score } & \multicolumn{2}{|c|}{ Best eye response (E) } \\
\hline \multicolumn{3}{|l|}{ I } & \multicolumn{2}{|c|}{ No eye opening } \\
\hline \multicolumn{3}{|l|}{2} & \multicolumn{2}{|c|}{ Eye opening to pain } \\
\hline \multicolumn{3}{|l|}{3} & \multicolumn{2}{|c|}{ Eye opening to verbal command } \\
\hline \multicolumn{3}{|l|}{4} & \multicolumn{2}{|c|}{ Eyes open spontaneously } \\
\hline \multicolumn{3}{|l|}{ Score } & \multicolumn{2}{|c|}{ Best verbal response $(\mathrm{V})$} \\
\hline \multicolumn{3}{|l|}{ I } & \\
\hline \multicolumn{3}{|l|}{2} & \multicolumn{2}{|c|}{ Incomprehensible sounds } \\
\hline \multicolumn{3}{|l|}{3} & \multicolumn{2}{|c|}{ Inappropriate words } \\
\hline \multicolumn{3}{|l|}{4} & \multicolumn{2}{|c|}{ Confused } \\
\hline \multicolumn{3}{|l|}{5} & \multicolumn{2}{|c|}{ Oriented } \\
\hline \multicolumn{3}{|l|}{ Score } & \multicolumn{2}{|c|}{ Best motor response $(\mathrm{M})$} \\
\hline \multicolumn{3}{|l|}{ I } & \multicolumn{2}{|c|}{ No motor response } \\
\hline \multicolumn{3}{|l|}{2} & \multicolumn{2}{|c|}{ Extension to pain } \\
\hline \multicolumn{3}{|l|}{3} & \multicolumn{2}{|c|}{ Flexion to pain } \\
\hline \multicolumn{3}{|l|}{4} & \multicolumn{2}{|c|}{ Withdrawal from pain } \\
\hline 5 & & & Local & izing pain \\
\hline 6 & & & Obey & s commands \\
\hline $\begin{array}{l}\text { A come } \\
\text { moder }\end{array}$ & $\begin{array}{l}\text { score of } 13 \text { or } t \\
\text { e injury and } 80\end{array}$ & $\begin{array}{l}\text { igher correlates wi } \\
\text { r less a severe brail }\end{array}$ & $\begin{array}{l}\text { ith a } \\
\text { in inju }\end{array}$ & $\begin{array}{l}\text { iild brain injury, } 9-12 \text { is a } \\
y\end{array}$ \\
\hline & The pe & diatric Glasgow c & coma & scale $\mathrm{e}^{[41,42]}$ \\
\hline Score & Eye opening & Verbal response & & Motor response \\
\hline 6 & - & - & & $\begin{array}{l}\text { Normal, spontaneous, } \\
\text { obeys commands }\end{array}$ \\
\hline 5 & - & $\begin{array}{l}\text { Age-appropriate } \\
\text { words, social smil } \\
\text { fixes and follows }\end{array}$ & & Localizes pain \\
\hline 4 & Spontaneous & Cries, but consola & lable & Withdraws from pain \\
\hline 3 & To voice & Persistently irritak & & Flexion posture to pain \\
\hline 2 & To pain & Restless agitated & & Extension posture to pain \\
\hline I & None & None & & None \\
\hline
\end{tabular}

\section{Conclusion}

Prediction models do face many challenges. Some of the desirable characteristics of risk-adjusted mortality predictors are that no lead-time bias should be present and they should not be affected by whether a patient is hospitalized or not. Albeit imperfect, the existing models have increased application in decision making at the right time and in decreasing hospital cost. It is also imperative that the choice of the severity score scale, index, or model accurately match the event, setting or application, as mis-application of such systems can result in avoidable wastage of time, increase in cost incorrect extrapolations and may contribute to mismanagement and death.

\section{References}

1. Knaus WA, Draper EA, Wagner DP, Zimmerman JE. APACHE II: A severity of disease classification system. Crit Care Med $1985 ; 13: 818-29$.

2. Bouch DC, Thompson JP. Severity scoring systems in the critically ill. Contin Educ Anaesth Crit Care Pain 2008;8:181-5.

3. Champion HR. Trauma scoring. Scand J Surg 2002;91:12-22.

4. Heldwein MB, Badreldin AM, Doerr F, Lehmann T, Bayer O, Doenst T, et al. Logistic Organ Dysfunction Score (LODS): A reliable postoperative risk management score also in cardiac surgical patients? J Cardiothorac Surg 2011;6:110.

5. Le Gall JR. The use of severity seores in the intensive eare unit. Intensive Care Med 2005;31:1618-23.

6. Pettilä V, Pettilä M, Sarna S, Voutilainen P, Takkunen O. Comparison of multiple organ dysfunction scores in the prediction of hospital mortality in the critically ill. Crit Care Med 2002;30:1705-11.

7. Maccariello ER, Valente C, Nogueira L, Ismael M, Valença RV, Machado JE, et al. Performance of six prognostic scores in critically ill patients receiving renal replacement therapy. Rev Bras Ter Intensiva $2008 ; 20(2): 115-123$.

8. Afessa B, Gajic O, Keegan MT. Severity of illness and organ failure assessment in adult intensive care units. Crit Care Clin $2007 ; 23: 639-58$.

9. Meyer AA, Messick WJ, Young P, Baker CC, Fakhry S, Muakkassa F, et al. Prospective comparison of clinical judgment and APACHE II score in predicting the outcome in critically ill surgical patients. J Trauma 1992;32:747-53.

10. Peter JV, Thomas L, Graham PL, Moran JL, Abhilash KP, Jasmine $\mathrm{S}$, et al. Performance of clinical scoring systems in acute organophosphate poisoning. Clin Toxicol (Phila) 2013;51:850-4.

11. Vincent JL, Bruzzi de Carvalho F. Severity of illness. Semin Respir Crit Care Med 2010;31:31-8.

12. Knaus WA, Wagner DP, Draper EA, Zimmerman JE, Bergner M, Bastos PG, et al. The APACHE III prognostic system. Risk prediction of hospital mortality for critically ill hospitalized adults. Chest 1991;100:1619-36.

13. Rubenfeld GD, Angus DC, Pinsky MR, Curtis JR, Connors AF Jr, Bernard GR. Outcomes research in critical care: Results of the American Thoracic Society Critical Care Assembly Workshop on Outcomes Research. The Members of the Outcomes Research Workshop. Am J Respir Crit Care Med 1999;160:358-67.

14. Zimmerman JE, Kramer AA, MeNair DS, Malila FM, Shaffer VL. Intensive care unit length of stay: Benchmarking based on Acute Physiology and Chronic Health Evaluation (APACHE) IV. Crit Care Med 2006;34:2517-29.

15. Le Gall JR, Lemeshow S, Saulnier F. A new Simplified Acute Physiology Score (SAPS II) based on a European/North American multicenter study. JAMA 1993;270:2957-63.

16. Le Gall JR, Neumann A, Hemery F, Bleriot JP, Fulgencio JP, Garrigues B, et al. Mortality prediction using SAPS II: An update for 
French intensive care units. Crit Care 2005;9:R645-52.

17. Metnitz PG, Moreno RP, Almeida E, Jordan B, Bauer P, Campos RA, et al. SAPS 3 - From evaluation of the patient to evaluation of the intensive care unit. Part 1: Objectives, methods and cohort description. Intensive Care Med 2005;31:1336-44.

18. Moreno RP, Metnitz PG, Almeida E, Jordan B, Bauer P, Campos RA, et al. SAPS 3 - From evaluation of the patient to evaluation of the intensive care unit. Part 2: Development of a prognostic model for hospital mortality at ICU admission. Intensive Care Med 2005;31:1345-55.

19. Liu V, Turk BJ, Ragins AI, Kipnis P, Escobar GJ. An electronic Simplified Acute Physiology Score-based risk adjustment score for critical illness in an integrated healthcare system. Crit Care Med 2013;41:41-8.

20. Marshall JC, Cook DJ, Christou NV, Bernard GR, Sprung CL, Sibbald WJ. Multiple organ dysfunction score: A reliable descriptor of a complex clinical outcome. Crit Care Med 1995;23:1638-52.

21. Vincent JL, Moreno R, Takala J, Willatts S, De Mendonça A, Bruining H, et al. The SOFA (Sepsis-related Organ Failure Assessment) score to describe organ dysfunction/failure. On behalf of the Working Group on Sepsis-Related Problems of the European Society of Intensive Care Medicine. Intensive Care Med 1996;22:707-10.

22. Vincent JL, de Mendonça A, Cantraine F, Moreno R, Takala J, Suter PM, et al. Use of the SOFA score to assess the incidence of organ dysfunction/ failure in intensive care units: Results of a multicenter, prospective study. Working group on "sepsis-related problems" of the European Society of Intensive Care Medicine. Crit Care Med 1998;26:1793-800.

23. Arts DG, de Keizer NF, Vroom MB, de Jonge E. Reliability and accuracy of Sequential Organ Failure Assessment (SOFA) scoring. Crit Care Med 2005;33:1988-93.

24. Ferreira FL, Bota DP, Bross A, Mélot C, Vincent JL. Serial evaluation of the SOFA score to predict outcome in critically ill patients. JAMA 2001;286:1754-8.

25. Bale C, Kakrani AL, Dabadghao VS, Sharma ZD. Sequential organ failure assessment score as prognostic marker in critically ill patients in a tertiary care intensive care unit. Int J Med Public Health 2013;3:155-8.

26. Vosylius S, Sipylaite J, Ivaskevicius J. Sequential organ failure assessment score as the determinant of outcome for patients with severe sepsis. Croat Med J 2004;45:715-20.

27. Grissom CK, Orme JF, Jensen RL, Jephson AR. A modified sequential organ failure assessment (SOFA) score to predict mortality in critically-ill patients. Crit Care Med 2007;35:A9.

28. Le Gall JR, Klar J, Lemeshow S, Saulnier F, Alberti C, Artigas A, et al. The logistic organ dysfunction system. A new way to assess organ dysfunction in the intensive care unit. ICU Scoring Group. JAMA 1996;276:802-10.

29. Timsit JF, Fosse JP, Troché G, De Lassence A, Alberti C, Garrouste-Orgeas M, et al. Calibration and discrimination by daily logistic organ dysfunction scoring comparatively with daily sequential organ failure assessment scoring for predicting hospital mortality in critically ill patients. Crit Care Med 2002;30:2003-13.

30. Kim TK, Yoon JR. Comparison of the predictive power of the LODS and APACHE II scoring systems in a neurological intensive care unit. J Int Med Res 2012;40:777-86.

31. Lemeshow S, Klar J, Teres D, Avrunin JS, Gehlbach SH, Rapoport J, et al. Mortality probability models for patients in the intensive care unit for 48 or 72 hours: A prospective, multicenter study. Crit Care Med 1994;22:1351-8.

32. Lemeshow S, Teres D, Avrunin JS, Gage RW. Refining intensive care unit outcome prediction by using changing probabilities of mortality Crit Care Med 1988;16:470-7.

33. Lemeshow S, Teres D, Klar J, Avrunin JS, Gehlbach SH, Rapoport J. Mortality Probability Models (MPM II) based on an international cohort of intensive care unit patients. JAMA 1993;270:2478-86.

34. Lemeshow S, Le Gall JR. Modeling the severity of illness of ICU patients. A systems update. JAMA 1994;272:1049-55.

35. Fagon JY, Chastre J, Novara A, Medioni P, Gibert C. Characterization of intensive care unit patients using a model based on the presence or absence of organ dysfunctions and/or infection: The ODIN model. Intensive Care Med 1993;19:137-44.

36. Timsit JF, Fosse JP, Troché G, De Lassence A, Alberti C, Garrouste-Orgeas M, et al. Accuracy of a composite score using daily SAPS II and LOD scores for predicting hospital mortality in ICU patients hospitalized for more than $72 \mathrm{~h}$. Intensive Care Med 2001;27:1012-21.

37. Teasdale G, Jennett B. Assessment of coma and impaired consciousness. A practical scale. Lancet 1974;2:81-4.

38. Castello FV, Cassano A, Gregory P, Hammond J. The Pediatric Risk of Mortality (PRISM) Score and Injury Severity Score (ISS) for predicting resource utilization and outcome of intensive care in pediatric trauma. Crit Care Med 1999;27:985-8.

39. Cantais E, Paut O, Giorgi R, Viard L, Camboulives J. Evaluating the prognosis of multiple, severely traumatized children in the intensive care unit. Intensive Care Med 2001;27:1511-7.

40. Kumaraswamy N, Naziah A, Abdullah J, Ariff MMed AR, Abdullah MR, Ghazaime G. Outcome of children with traumatic brain injury in rura Malaysia. J Clin Neurosci 2002;9:251-5.

41. Hahn YS, Fuchs S, Flannery AM, Barthel MJ, McLone DG. Factors influencing posttraumatic seizures in children. Neurosurgery 1988;22:864-7.

42. Raimondi AJ, Hirschauer J. Head injury in the infant and toddler. Coma scoring and outcome scale. Childs Brain 1984;11:12-35.

How to cite this article: Rapsang AG, Shyam DC. Scoring systems in the intensive care unit: A compendium. Indian J Crit Care Med 2014;18:220-8.

Source of Support: Nil, Conflict of Interest: None declared. 